\title{
Nutritional status and blood pressure in adolescent students
}

\author{
Marco Cossio-Bolaños, M.D. .,b $^{a,}$ Wilbert Cossio-Bolaños, Magister, ${ }^{c, d}$ \\ Adriana Araya Menacho, B.S. ${ }^{e}$, Rossana Gómez Campos, M.D.f,g, \\ Yuri Muniz da Silva, B.S.f, Carlos Pablos Abella, M.D. ${ }^{h}$ and Miguel de Arruda, M.D.f
}

\begin{abstract}
Introduction. Obesity is the main risk factor for arterialhypertension and is associated with ahigher morbidity, both in the short and long term.

Objectives. To compare anthropometric and blood pressure indicators in terms of the nutritional status, to verify the relationship between nutritional status and blood pressure, and to establish the prevalence of hypertension in terms of the nutritional status in both male and female adolescents.

Methods. Cross-sectional, descriptive study on 499 adolescent students aged 11-15 years old Weight, height, body mass index (BMI), fat percentage, and blood pressure were measured and assessed. The BMI was used to classify participants (normal weight, overweight, obese), and the prevalence of hypertension was determined using values above the $95^{\text {th }}$ percentile.

Results. As per the BMI classification, $81 \%$ of girls and $76.5 \%$ of boyshad normal weight, $15.7 \%$ of girls and $15.5 \%$ of boys were overweight, and $3.3 \%$ of girls and $8 \%$ of boys were obese. As per the blood pressure classification, hypertension was observed in $6.4 \%$ of boys and in $9 \%$ of girls. A relationship was found between nutritional status and blood pressure (boys: $\mathrm{c}_{2}=53.48$; girls: $\mathrm{c}_{2}=85.21$ ).

Conclusion. Overweight and obese adolescents had more body fat and a higher blood pressure than normal weight adolescents. Also, a relationship was determined between nutritional status and blood pressure in both male and female students. The higher the BMI, the higher the prevalence of hypertension.

Key words: overweight, obesity, blood pressure, body mass index, adolescents.
\end{abstract}

http:/ /dx.doi.org/10.5546/aap.2014.eng.302

\section{INTRODUCTION}

Nutritional status refers to the situation a person is in relation to food intake and to the physiological adaptations that take place following nutrient consumption. The objective of assessing nutritional status is to determine growth and body proportions of an individual or a community so as to establish whether interventions are required. ${ }^{1}$

During the growth and development stage, it is necessary to perform regular evaluations of the nutritional status. In fact, adolescence is particularly characterized by being a critical period of intense biological, psychological and cognitive changes. ${ }^{2}$ In this stage, the main nutritional problems affecting adolescents are malnutrition, underweight, overweight, and obesity. In general, malnutrition reduces work capacity, resistance to physical stress and the ability to focus, and overeating predisposes to chronic conditions, including diabetes and cardiovascular disease. $^{3}$

At present, South America is going through a demographic and epidemiological transition. Some studies have highlighted that this region of the continent has gone from a high prevalence of low weight and growth disorders to a marked increase in obesity that accompanies chronic conditions. ${ }^{4}$ In fact, Peru is at a stage of nutritional transition, ${ }^{5}$ and it is therefore necessary and critical to study the changes in the nutritional profile of Peruvian children and adolescents given that overweight increase has been continuous in developing and developed countries, ${ }^{6}$ including Peru. ${ }^{7}$

Currently, blood pressure is one of the clinical outcome measures used to evaluate cardiovascular risk and can be easily measured in the school setting, therefore enabling the detection of arterial hypertension at an early age, ${ }^{9}$ given that obesity is the main risk factor of this condition ${ }^{10}$ among children and adolescents. Obesity is associated with a higher morbidity, both in the short and long term ${ }^{11}$ and, above all, it is considered a public health problem. ${ }^{12}$

In this context, no studies have been conducted to assess the 
nutritional status and blood pressure of Peruvian children and adolescents. For this reason, it is necessary to describe such outcome measures in urban schools because, over the past years, there has been greater interest in knowing the prevalence of overweight and obesity and in establishing the prevalence of hypertension at an early age. Based on this, the following are the study objectives: a) to compare anthropometric and blood pressure indicators in terms of the nutritional status, b) to verify the relationship between nutritional status and blood pressure, and c) to establish the prevalence of hypertension in terms of the nutritional status in both male and female students.

\section{METHODS}

This is a cross-sectional, descriptive study. The sample consists of male and female adolescent students aged 12-15 years old. Adolescents were selected in a non-probabilistic (accidental) fashion. All students attend the Liceo Naval Contralmirante Lizardo Montero, located in the district of San Miguel (Lima). This is one of the 43 districts in the province of Lima; it is part of the urban area, mostly residential and a major metropolitan commercial center.

All adolescents whose legal tutors and/or parents had signed the informed consent letter and who attended the school on the assessment day were included in the study. Students who had some physical or motor impairment, were underweight, were receiving medications and those who did not complete the informed consent form were excluded.

Place of birth was checked as per birth certificates provided by the school authorities. The study was approved by the Research Ethics Committee of the Centro Médico Naval-2006 (Lima, Peru).

\section{Procedures and techniques}

Data were collected by means of a direct interview. All data (student ID code, age, sex, anthropometric outcome measures and blood pressure values) were recorded in an individual evaluation file.

The decimal age of each studied student was determined by recording the date of birth (day, month, year) and the date of the anthropometric assessment (day, month, year), and using a record table.

For the assessment of anthropometric outcome measures, the standards and recommendations of the International Society for the Advancement of
Kinanthropometry (ISAK) were used, which have been described and detailed by Ross and MarfellJones. ${ }^{13}$ The studied anthropometric measures were:

- Body mass (kg): measured with a Tanita digital scale, with a $100 \mathrm{~g}$ precision and a range from 0 to $150 \mathrm{~kg}$.

- Height (m): measured using a Seca aluminum stadiometer graduated in millimeters with a range from 0 to $2.50 \mathrm{~m}$.

- Tricipital and subscapular skinfold thickness $(\mathrm{mm})$ was measured following the natural cleavage lines of the skin with a Harpenden caliper at a constant standard pressure of $10 \mathrm{~g} / \mathrm{mm}^{2}$.

Weight, height and skinfold anthropometric outcome measures were assessed by two of the study authors, who have a broad experience in the field and a level III ISAK certification. Intraevaluator technical error of measurement (TEM) ranges from $1 \%$ to $3 \%$.

Body mass index $\left(\mathrm{kg} / \mathrm{m}^{2}\right)$ was measured to establish the relationship between weight and height using the Quetelet index: [BMI= weight $(\mathrm{kg}) /$ height $(\mathrm{m})^{2}$. Nutritional status was established based on the BMI as per age and sex. Cut-off points were determined according to the CDC-2000, ${ }^{14}$ and were as follows: underweight < p5; normal weight from p5 to p85; overweight from p85 to p95; and obese > p95.

The percentage of body fat $(\% \mathrm{~F})$ was determined by the regression equation proposed by Boileau, et al: ${ }^{15}$

$$
\% \mathrm{~F}=1.35(\mathrm{TR}+\mathrm{SS})-0.012(\mathrm{TR}+\mathrm{SS}) 2-4.4 \text { for }
$$
boys.

$$
\% \mathrm{~F}=1.35(\mathrm{TR}+\mathrm{SS})-0.012(\mathrm{TR}+\mathrm{SS}) 2-2.4 \text { for }
$$
girls.

Blood pressure (BP) was determined based on the Pan American Health Organization (PAHO) recommendations; $;^{16}$ values were recorded after at least 10 minutes at rest. A mercury sphygmomanometer and a stethoscope (Riester) were used to measure BP with the subject sitting on a chair, with the back against the back of the chair, feet resting on the floor and the right arm with no clothes on and reaching out over a table (at the level of the heart). Systolic blood pressure (SBP) and diastolic blood pressure (DBP) were recorded as per Korotkoff's phase I and V sounds. According to the National High Blood Pressure Education Program Working Group on Hypertension Control in Children and Adolescents ${ }_{1}^{17}$ values above the $95^{\text {th }}$ percentile were considered arterial hypertension. BP 
assessment was conducted by one of the authors, who is a highly experienced nurse. BP was measured twice, with a TEM below $4 \%$.

\section{Statistical analysis}

Data normality was verified using ShapiroWilk's test. Results were analyzed applying the following descriptive statistics: arithmetic mean, standard deviation (SD), frequency and percentage. Differences between sexes were obtained using the $t$ test for independent samples. The relationship among outcome measures was established using a chi-square test $\left(\chi^{2}\right)$ for each sex. Differences among age, anthropometric outcome measures and BP as per the nutritional status were compared using a two-way analysis of variance (ANOVA). A value of $p<0.05$ was used in all statistical analysis.

\section{RESULTS}

The sample consisted of 251 male students and 248 female students.

The overall characteristics of studied students are presented in Table 1. Boys have a higher body weight and height when compared to girls, who in turn have a higher body fat percentage than boys. In addition, in terms of nutritional status, male students have a higher prevalence of obesity and hypertension than their female counterparts.

Mean \pm SD values for anthropometric outcome measures and blood pressure in male and female adolescents in terms of their nutritional status are presented in Table 2. Significant differences were observed in the normal weight, overweight and obese categories for every anthropometric outcome measure and for systolic blood pressure. No significant differences were found in relation to diastolic blood pressure among male and female adolescents in the normal weight and overweight groups; however, differences were observed among these and the obese group.

In general, the age and height outcome measures showed no differences between males and females when classified by nutritional status.

The relationship between nutritional status and blood pressure is presented in Table 3 . Results indicate that there is a relationship between these two outcome measures both in boys and girls (boys: $\chi^{2}=53.48$; girls: $\chi^{2}=85.21$ ).

In relation to the prevalence of arterial hypertension, results show that $6.4 \%$ of boys and $3.6 \%$ of girls have this condition. In both sexes, the prevalence of hypertension increases with each nutritional status category, for example, the presence of hypertension increased from 1.2\% (normal weight) to $3.2 \%$ (obese) among the boys, while it raised from $0.4 \%$ (normal weight) to $2 \%$ (obese) among the girls. In general, the prevalence of hypertension was higher in boys than in girls.

\section{DISCUSSION}

Although the study anthropometric data show a clear sexual dimorphism (males are taller and heavier than females), systolic and diastolic blood pressure values did not show significant difference between sexes. These results are consistent with those of other studies ${ }^{18,19}$ which describe similar values in male and female adolescents.

Table 1. General characteristics of the studied sample

\begin{tabular}{|c|c|c|c|c|}
\hline \multirow[t]{2}{*}{ Outcome measures } & \multicolumn{2}{|c|}{ Boys $(n=251)$} & \multicolumn{2}{|c|}{ Girls $(n=248)$} \\
\hline & $\mathbf{x}$ & SD & $\mathbf{x}$ & SD \\
\hline Age (years) & 13.3 & 0.9 & 13.3 & 1.0 \\
\hline Weight (kg) & 52.4 & 9.4 & 50.2 & $8.2^{*}$ \\
\hline Height $(\mathrm{cm})$ & 159.5 & 8.5 & 154.3 & $5.4^{*}$ \\
\hline $\operatorname{BMI}\left(\mathrm{kg} / \mathrm{m}^{2}\right)$ & 20.5 & 2.8 & 21.0 & 2.9 \\
\hline Fat percentage $(\% \mathrm{~F})$ & 19.9 & 7.2 & 28.0 & $5.3^{*}$ \\
\hline Systolic blood pressure $(\mathrm{mmHg})$ & 104.2 & 14.1 & 102.2 & 12.4 \\
\hline Diastolic blood pressure ( $\mathrm{mmHg}$ ) & 64.9 & 8.2 & 63.1 & 10.8 \\
\hline BMI classification & $\mathbf{n}$ & $\%$ & $\mathbf{n}$ & $\%$ \\
\hline Normal weight & 192 & 76.5 & 201 & 81.0 \\
\hline Overweight & 39 & 15.5 & 39 & 15.7 \\
\hline Obese & 20 & 8.0 & 8 & 3.3 \\
\hline \multicolumn{5}{|l|}{ BP classification } \\
\hline Normotensive & 235 & 93.6 & 239 & 96.4 \\
\hline Hypertensive & 16 & 6.4 & 9 & 3.6 \\
\hline
\end{tabular}


TABLE 2. Mean values ( \pm SD) of anthropometric and blood pressure indicators, classified as normal weight, overweight and obese as per the BMI

\begin{tabular}{|c|c|c|c|c|c|c|}
\hline \multirow[t]{2}{*}{ Outcome measures } & \multicolumn{2}{|c|}{ Normal weight } & \multicolumn{2}{|c|}{ Overweight } & \multicolumn{2}{|c|}{ Obese } \\
\hline & $x$ & SD & $\mathbf{x}$ & SD & $x$ & SD \\
\hline \multicolumn{7}{|l|}{ Boys $(n=251)$} \\
\hline Age (years) & 13.37 & 0.90 & 13.21 & 0.88 & 13.15 & 0.91 \\
\hline Weight (kg) & 49.34 & 7.17 & 60.37 & $7.23^{\mathrm{a}}$ & 65.60 & $11.38^{\mathrm{a}, \mathrm{b}}$ \\
\hline Height $(\mathrm{cm})$ & 159.58 & 8.21 & 160.77 & 8.33 & 157.00 & 11.00 \\
\hline $\operatorname{BMI}\left(\mathrm{kg} / \mathrm{m}^{2}\right)$ & 19.29 & 1.70 & 23.26 & $0.83^{\mathrm{a}}$ & 26.53 & $1.60^{\mathrm{a}, \mathrm{b}}$ \\
\hline Fat percentage $(\% \mathrm{~F})$ & 17.45 & 5.66 & 25.76 & $6.19^{a}$ & 31.98 & $1.35^{\mathrm{a}, \mathrm{b}}$ \\
\hline Systolic blood pressure (mmHg) & 102.97 & 14.95 & 106.28 & $10.36^{\mathrm{a}}$ & 112.00 & $8.12^{\mathrm{a}, \mathrm{b}}$ \\
\hline Diastolic blood pressure $(\mathrm{mmHg})$ & 64.56 & 8.11 & 64.49 & 8.46 & 69.25 & $7.12^{\mathrm{a}, \mathrm{b}}$ \\
\hline \multicolumn{7}{|l|}{ Girls $(n=248)$} \\
\hline Age (years) & 13.41 & 0.99 & 12.87 & 0.79 & 12.75 & 0.83 \\
\hline Weight $(\mathrm{kg})$ & 47.83 & 6.19 & 58.55 & $6.58^{\mathrm{a}}$ & 68.63 & $8.59^{\mathrm{a}, \mathrm{b}}$ \\
\hline Height $(\mathrm{cm})$ & 154.25 & 5.28 & 154.36 & 5.86 & 155.13 & 6.62 \\
\hline BMI $\left(\mathrm{kg} / \mathrm{m}^{2}\right)$ & 20.06 & 2.03 & 24.49 & $1.38^{\mathrm{a}}$ & 28.46 & $2.84^{\mathrm{a}, \mathrm{b}}$ \\
\hline Fat percentage $(\% \mathrm{~F})$ & 26.76 & 5.07 & 29.07 & $1.82^{\mathrm{a}}$ & 33.13 & $2.76^{\mathrm{a}, \mathrm{b}}$ \\
\hline Systolic blood pressure (mmHg) & 102.00 & 12.34 & 105.62 & $13.10^{\mathrm{a}}$ & 110.63 & $7.26^{\mathrm{a}, \mathrm{b}}$ \\
\hline Diastolic blood pressure $(\mathrm{mmHg})$ & 62.31 & 8.35 & 63.90 & 18.50 & 68.75 & $10.53^{\mathrm{a}, \mathrm{b}}$ \\
\hline
\end{tabular}

a,b: significant difference $(\mathrm{p}<0.05)$; a: significant difference from the normal weight category;

b: significant difference from the overweight category; BMI: body mass index; SD: standard deviation.

TABLE 3. Relationship between nutritional status and blood pressure in adolescents

\begin{tabular}{lcccc}
\hline Categories & Normal weight & Overweight & Obese & Total \\
\hline Boys & & & & \\
$\quad$ Normotensive & $189(75.3)$ & $36(14.3)$ & $10(4.0)$ & $235(93.6)$ \\
Hypertensive & $3(1.2)$ & $5(2.0)$ & $8(3.2)$ & $16(6.4)$ \\
Total & $192(76.5)$ & $41(16.3)$ & $18(0.2)$ & $251(100)$ \\
Girls & & & & \\
$\quad$ Normotensive & $188(75.8)$ & $48(19.4)$ & $3(1.2)$ & $239(96.4)$ \\
Hypertensive & $1(0.4)$ & $3(1.2)$ & $5(2.0)$ & $9(3.6)$ \\
Total & $181(75.3)$ & $51(20.6)$ & $8(3.2)$ & $240(100)$ \\
\hline
\end{tabular}

Boys: $\chi^{2}=53.48(\mathrm{p}<0.0001)$; girls: $\chi^{2}=85.21(\mathrm{p}<0.05)$.

Comparisons among anthropometric and blood pressure indicators in terms of the nutritional status evidenced significant differences among the nutritional categories (normal weight, overweight and obese) in both sexes. As expected, these findings indicate that overweight and obese adolescents have higher values of weight, BMI and fat percentage; at the same time, they show elevated mean blood pressure values when compared to normal weight adolescents.

In this sense, it is worth noting that several studies have determined such differences in children ${ }^{20,21}$ and adolescents ${ }^{22,23}$ who were classified as overweight and obese as per anthropometric indicators, and who are characterized by having higher values of central body fat, waist circumference and BMI, and who also showed higher blood pressure values. This clearly is part of the urban reality of Lima, where values were relatively similar to those obtained in the other mentioned studies.

In general, research has demonstrated that children and adolescents with high blood pressure are more prone to developing arterial hypertension as adults. ${ }^{24,25}$ Excess weight and body fat during growth are associated with high plasma levels of insulin, lipids and lipoproteins; ${ }^{25}$ as a result, health risks are higher and force governments to adopt strategies aimed at controlling the obesity epidemics.

A significant relationship was found between nutritional status and blood pressure. These study findings are consistent with those of other studies, ${ }^{26,27}$ although the criteria applied to define high blood pressure and establish nutritional status categories may not have been the same. However, using the BMI in our study has allowed us to establish that BMI is an adequate indicator 
which can be used to identify a risk factor for hypertension in male and female adolescents. Actually, the prevalence of arterial hypertension in our study increases with each nutritional status (normal weight, overweight, obesity). A higher prevalence was observed in male and female obese adolescents, and it is relatively higher in boys $(3.2 \%)$ when compared to girls $(2 \%)$.

Some international research conducted in adolescents showed a higher prevalence of hypertension ${ }^{19,28}$ than this study, although the prevalence of hypertension during childhood and adolescence is not clearly defined; in general, studies estimate that between $1 \%$ and $4 \%$ of the pediatric population have hypertension, ${ }^{29,30}$ and these values may differ based on age, sex, height, race, eating habits, physical activity and geographic conditions. In fact, the exact prevalence of hypertension in the pediatric population worldwide is still unknown, ${ }^{31}$ although Muntner, et al. ${ }^{32}$ consider that hypertension rates have increased over the past years in children.

Therefore, a regular and systematic blood pressure assessment of pediatric patients is a critical tool for the early detection of this condition, which is the leading cause of premature death in adults worldwide, including developed, developing and underdeveloped countries. ${ }^{6}$ In addition, it is worth noting that no other national study has been conducted that would allow us compare and better analyze our results, although this is an early evidence of the presence of hypertension in Peruvian adolescent students.

These study findings are consistent with those in previous studies, ${ }^{33,34}$ where obese subjects were found to be more prone to hypertension than thin subjects. Besides, several risk factors have been associated with lifestyle, ${ }^{27}$ such as lack of physical activity and eating disorders.

To sum up, the growing number of obese children and adolescents worldwide, particularly in Peru, ${ }^{7}$ will probably call for higher costs to prevent obesity-associated conditions.

Basically, our study has some limitations. For example, the sample was selected in a nonprobabilistic fashion, which does not allow to generalize results to other contexts and limited the studied sample. Also, not having included physical activity and eating habits as primary parameters may lead to bias in our results because if such outcome measures had been included, it would have allowed us to better discuss our findings considering that physical activity is essential for children and adolescents to have adequate physical performance and eating habits.

Dietz ${ }^{35}$ believes that, in the end, adolescents fulfill their energy requirements with foods high in saturated fat, sugar and sodium, which are harmful for their health at an early age.

\section{CONCLUSIONS}

Based on our results, it has been determined that overweight and obese adolescents have more body fat and a higher blood pressure than normal weight adolescents. Also, a relationship was established between nutritional status and blood pressure in both male and female students. The prevalence of hypertension was higher as the body mass index increased. Establishing the BMI value and measuring blood pressure should become a routine approach in regular pediatric checkups throughout growth.

\section{REFERENCES}

1. Sigulem DM, Devincenzi MU, Lessa AC. Diagnóstico do estado nutricional da crianca e do adolescente. J Pediatr (Rio J.) 2000;76 (Supl.3):S275-84.

2. Stang J, Story M. Adolescent Growth and development. En: Stang J, Story M, eds. Guidelines for Adolescent Nutrition Services. Minneapolis: University of Minnesota, 2005: 1-8.

3. World Health Organization (WHO). Improvement of Nutritional Status of Adolescents, 2002. [Acceso 5 de febrero de 2014]. Disponible en: http://apps.searo.who. int/ pds_docs/B3526.pdf.

4. Rivera JA, Barquera S, Gonzalez-Cossio T, Olaiz G, Sepúlveda J. Nutrition transition in Mexico and in other Latin American countries. Nutr Rev 2004;62 (7 Pt 2):S149-57.

5. Mispireta ML, Rosas AM, Velásquez JE, Lescano AG, Lanata CF. Transición nutricional en el Perú, 1991-2005. Rev Peru Med Exp Salud Pública 2007;24(2):129-35.

6. Chobanian AV, Bakris GL, Black HR, Cushman WC, et al. The seventh report of the joint national committee on prevention, detection, evaluation, and treatment of high blood pressure: the JNC 7 Report. JAMA 2003;289(19):2560-72.

7. Instituto Nacional de Estadística e Informática. Encuesta Demográfica y de Salud Familiar. 2005. Lima: INEI; 2006.

8. Szer G, Kovalskys I, De Gregorio MJ. Prevalencia de sobrepeso, obesidad y su relación con hipertensión arterial y centralización del tejido adiposo en escolares. Arch Argent Pediatr 2010;108(6):492-8.

9. Beck CC, Lopes AS, Pitanga FG. Indicadores Antropométricos como Predictores de Presión Arterial Elevada en Adolescentes. Arq Bras Cardiol 2011;96(2):126-33.

10. González-Jiménez E, Aguilar-Cordero MJ, García-García CJ, García-López PA, et al. Prevalencia de sobrepeso y obesidad nutricional e hipertensión arterial y su relación con indicadores antropométricos en una población de escolares de Granada y su provincia. Nutr Hosp 2011;26(5):1004-10.

11. Maffeis C,MoghettiP,Grezzani A,Clementi M, et al. Insulin resistance and the persistence of obesity from childhood into adulthood. J Clin Endocrinol Metab 2002;87(1):71-6.

12. Cordero A, Lekuona I, Galve E, Mazón P. Novedades en hipertensión arterial y diabetes mellitus. Rev Esp Cardiol 2012;65(Supl 1):12-23.

13. Ross WD, Marfell-Jones MJ. Kinanthropometry. En:Mac- 
Dougall JD, Wenger HA, Geen HJ, eds. Physiological testing of eliteathlete. London: Human Kinetics;1991:223-308.

14. Kuczmarski R, Ogden C, Grummer-Strawn L, Flegal K, et al. CDC Growth Charts: United States. Advance data from vital and health statistics ( $\left.{ }^{\circ} 314\right)$. Hyattsville (MD): U.S. Department of Health and Human Services; 2000.

15. Boileau RA, Lohman TG, Slaughter MH. Exercise and body composition in children and youth. Scan J Sports Sci 1985;7:17-27.

16. Iniciativa Panamericana sobre la Hipertensión. Reunión de trabajo sobre la medición de la presión arterial: recomendaciones para estudios de población. Rev Panam Salud Pública 2003;14(5):303-5.

17. Updateonthe1987TaskForcereportonhighbloodpressurein children and adolescents: a working group report from the National High Blood Pressure Education Program. National High Blood Pressure Education Program working group on hypertensioncontrolinchildrenandadolescents. Pediatrics 1996;98(4 Pt 1):649-58.

18. Freedman DS, Dietz WH, Srinivasan SR, Berenson GS. The relation of overweight to cardiovascular risk factors among children and adolescents; the Bogalusa study. Pediatrics 1999;103(6 Pt 1):1175-82.

19. Poletti OH, Pizzorno J, Barrios L. Valores medios de tensión arterial en escolares de 10 a 15 años de la ciudad de Corrientes, Argentina. Arch Argent Pediatr 2006;104(3):210-6.

20 Giugliano R, Melo AL. Diagnóstico de sobrepeso e obesidade em escolares: utilizacáo do índice de massa corporal segundo padráo internacional. J Pediatr (Rio J) 2004;80(2):129-34.

21. Baruki SB, Rosado LE, Rosado GP, Ribeiro RC. Associacáo entre estado nutricional e atividade física em escolares da Rede Municipal de Ensino em Corumbá - MS. Rev Bras Med Esporte 2006,12(2):90-4.

22. Burrows R, Burgueño M, Leiva L, Ceballos X, et al. Perfil metabólico deriesgocardiovascularen niñosy adolescentes obesos con menor sensibilidad insulínica. Rev Méd Chile 2005;133(7):795-804.

23. Ortiz-Pérez H, Molina-Frechero N, Castañeda-Castaneira E. Indicadores antropométricos de sobrepeso-obesidad en adolescentes. Rev Mex Pediatr 2010;77(6);241-7.

24. Weiss R, Dufour S, Taksali SE, Tamborlane WV, et al. Prediabetes in obese youth: a syndrome of impaired glucose tolerance, severe insulin resistance, and altered myocellular and abdominal fat partitioning. Lancet 2003;362(9388):951-7.

25. Schiel R, Beltschikow W, Kramer G, Stein G. Overweight, obesity and elevated blood pressure in children and adolescents. Eur J Med Res 2006;11(3):97-101.

26. Guerra S, Duarte J, Mota J. Physical activity and cardiovascular disease risk factors in schoolchildren. Eur Phys Educ Rev 2001;7, 269-81.

27. Ribeiro J, Guerra S, Pinto A, Oliveira J, et al. Overweight and obesity in children and adolescents: relationship with blood pressure, and physical activity. Ann Hum Biol 2003;30(2):203-13.

28. Ferreira JS, Aydos RD. Prevalencia de hipertensáo arterial em criancas e adolescentes obesos. Ciénc Saúde Colet 2010;15(1):97-104.

29. Sorof JM, Lai D, Turner J, Poffenbarger T, Portman RJ. Overweight, ethnicity, and the prevalence of hypertension in school-aged children. Pediatrics 2004;113(3 Pt 1):475-82.

30. Jago R, Harrell JS, McMurray RG, Edelstein S, et al. Prevalence of abnormal lipid and blood pressure values among an ethnically diverse population of eighth grade adolescents and screening implications. Pediatrics 2006;117(6):2065-73.

31. Falkner B. Hypertension in children and adolescents: epidemiology and natural history. Pediatr Nephrol 2010;25(7):1219-24.

32. Muntner P, He J, Cutler JA, Wildman RP, Whelton PK. Trends in blood pressure among children and adolescents. JAMA 2004;291(17):2107-13.

33. Schieken, RM. New perspectives in childhood blood pressure. Curr Opin Cardiol 1995;10(1):87-91.

34. Daniels SR, Morrison JA, Sprecher DL, Khoury P, Kimball TR. ssociation of fat distribution and cardiovascular risk factors in children and adolescents. Circulation 1999;99(4):541-5.

35. Dietz WH. Childhood weight affects adult morbidity and mortality. J Nutr 1998;128:(2 Suppl):S411-4. 